\title{
Serum infliximab measurement in inflammatory bowel disease patients in remission: a comparative analysis of two different methods in a multicentric Brazilian cohort
}

\author{
Fábio Vieira TEIXEIRA ${ }^{1,2}$, Ligia Yukie SASSAKI ${ }^{2}$, Rogerio SAAD-HOSSNE², Julio Pinheiro BAIMA², \\ Daniéla Oliveira MAGRO ${ }^{3}$, Claudio Saddy Rodrigues COY $^{3}$ and Paulo Gustavo KOTZE ${ }^{3,4}$
}

\begin{abstract}
Background - Infliximab (IFX) therapeutic drug monitoring is an important tool to guide therapeutic decision in inflammatory bowel disease patients. Currently, there are two methods to measure trough levels of IFX, ELISA assays or rapid tests. Despite that the ELISA assay is the most used method in therapeutic drug monitoring, the results take long to be available for clinical use, and it needs to be performed by trained personnel. In contrary, the results of a rapid test take 20 to 30 minutes to be available and can be performed by non-trained lab personnel. Objective - The aim of the study was to compare a rapid test (QB-IFX) for quantitative determination of IFX level to one ELISA assay in a cohort of inflammatory bowel disease patients. Methods - Cross-sectional multicentric study with 49 inflammatory bowel disease patients on maintenance therapy with IFX. Blood samples for IFX serum levels were collected immediately before infusion. IFX serum levels were classified as undetectable, low $(<3.0 \mu \mathrm{g} / \mathrm{mL})$, adequate $(3.1-7.0 \mu \mathrm{g} / \mathrm{mL})$ or high $(>7.1 \mu \mathrm{g} / \mathrm{mL})$. A sensitivity and specificity of each test and a comparison between tests was based on ROC curves. Results - Thirty-four Crohn's disease patients and 15 ulcerative colitis patients in clinical remission were evaluated. The majority of patients had low or adequate serum levels of IFX. In relation to the serum levels proportions with the two methods, there was no significant difference $(P=0.84)$. The ROC analysis identified a concentration threshold $>2.9 \mu \mathrm{g} / \mathrm{mL}$ with the QB-IFX test (area under the ROC, $0.82 ; P<0.0001$, sensitivity, $100 \%$; specificity, $61.9 \%$ ), and $>3.83 \mu \mathrm{g} / \mathrm{mL}$ using the ELISA assay (area under the ROC, $0.96 ; P<0.0001$, sensitivity, 100\%; specificity, $92.9 \%$ ). Conclusion - QB-IFX and ELISA assays to measure IFX levels were comparable. Both methods had accurate sensitivity and specificity to detect undetectable, low and adequate levels, but had showed low specificity for supra therapeutic levels of IFX.
\end{abstract}

HEADINGS - Crohn's disease. Proctocolitis. Infliximab. Drug monitoring.

\section{INTRODUCTION}

In the last two decades, the treatment of immune-mediated diseases had changed dramatically since the advent of tumornecrosis factor (TNF) alpha inhibitors, mostly known as anti-TNF agents. The available evidence on the importance and effectiveness of these agents in the treatment of rheumatic and dermatological conditions, such as rheumatoid arthritis (RA), ankylosing spondylitis (AS), psoriasis and psoriatic arthritis (PA) is solid. Moreover, these drugs were also proven to be effective in the management of major inflammatory bowel diseases (IBD), Crohn's disease (CD) and ulcerative colitis (UC) $)^{(1-6)}$.

In current clinical practice, the anti-TNF agents that are mostly used in Brazil are: etanercept (a fusion protein used in rheumatology and dermatology, not proven to be effective in the treatment of IBD); infliximab (IFX); adalimumab (ADA); certolizumab pegol
(CZP) and golimumab (GOL). In Brazil, GOL is currently approved for patients with RA and UC. The first anti-TNF agent approved for the treatment of IBD in our country was IFX, back in 2000.

Since it was the first anti-TNF to be approved for the management of IBD, IFX is the agent that concentrates most of the experience by gastroenterologists in treating $\mathrm{CD}$ and $\mathrm{UC}^{(7-11)}$. Recently, the dosage of IFX serum levels just before the following infusion (known as trough levels) and antibodies to IFX (ATI) has been used in clinical practice in order to monitor response and guide treatment optimization in cases of secondary loss of response to the drug, a strategy denominated as therapeutic drug monitoring (TDM $)^{(8-10)}$.

Therapeutic IFX levels are considered adequate when between 3.0 and $7.0 \mu \mathrm{g} / \mathrm{mL}^{(8-10)}$. Despite being in remission, some IBD patients on IFX therapy may experience undetectable, low, adequate or high trough levels. In 2015, Van de Casteele et al., studying a cohort of 275 patients from Leuven demonstrated remarkable find-

Declared conflict of interest of all authors: Teixeira FV is a speaker and consultant for Janssen, Ferring, Abbvie and Takeda; advisory board for Ferring and Janssen. Saad-Hossne R is a speake and consultant for Janssen and Abbvie. Kotze PG is a speaker and consultant of Abbvie, Janssen, Takeda and Pfizer.

Disclosure of funding: no funding received

${ }^{1}$ Clínica GastroSaúde, Marília, SP, Brasil. ${ }^{2}$ Universidade Estadual Paulista (UNESP), Campus de Botucatu, Ambulatório de Doenças Inflamatóticas Intestinais, Faculdade de Medicina, Botucatu, SP, Brasil. ${ }^{3}$ Unicamp, Faculdade de Ciências Médicas, Departamento de Cirurgia, Serviço de Coloproctologia, Campinas, SP, Brasil. ${ }^{4}$ PUCPR, Hospital Universitário Cajuru, Unidade de Cirurgia Colorretal, Curitiba, PR, Brasil.

Corresponding author: Fábio Vieira Teixeira. E-mail: fabio@gastrosaude.com 
ings. Of 275 patients in remission, IFX trough levels were above normal range ( $>7 \mu \mathrm{g} / \mathrm{mL})$ in $72(26.2 \%)$ patients. They found normal trough levels (between 3 and $7 \mu \mathrm{g} / \mathrm{mL}$ ) in $121(44.0 \%$ ) patients, low levels $(<3 \mu \mathrm{g} / \mathrm{mL})$ in $58(21.1 \%)$ patients and undetectable trough levels in $24(8.7 \%)$ patients ${ }^{(8)}$.

Although the routine use of TDM can be questioned, as a study from the Netherlands have demonstrated ${ }^{(11)}$, it is for sure helpful in making faster decisions in patients with secondary loss of response. This strategy is important to guide a switch in the agent or mechanism of action (when adequate levels, absence of response and antibodies are detected), or to simply increase the dose of the same agent, in case of negative antibodies detection and lower detected levels. However, conventional ELISA (enzymelinked immune sorbent assay) methods used so far for TDM, are usually performed at laboratories and are considerable time consuming procedures ${ }^{(8,10-22)}$. Thus, trough level results take one to two days to be available for the clinician. The late availability of this data, do not allow a possible dose escalation or de-escalation when the patient is already at the infusion unit ${ }^{(14-18)}$. In fact, with this drawbacks related to ELISA, TDM is quite difficult to be implemented.

ANVISA (Agência Nacional de Vigilância Sanitária), the Brazilian regulatory agency, has recently approved the first rapid test to measure IFX levels in Brazil, the Quantum Blue Infliximab test (QB-IFX, Bühlmann Laboratories, Basel, Switzerland). The great advantage of a rapid test is the availability of the results in 20 to 30 minutes, when the patient is still in the infusion unit ${ }^{(13,17)}$. However, there is a lack of studies that compared QB-IFX rapid test to the ELISA used in most IBD centers throughout the world ${ }^{(10,11,13,15,17)}$. Moreover, to date, there are few studies with serum levels measurement of IFX in Brazilian patients ${ }^{(12,13)}$.

The aim of the present study was to compare a rapid test (QB-IFX) for quantitative determination of IFX serum level to an ELISA in a cohort of IBD patients in clinical or endoscopic remission.

\section{METHODS}

\section{Study design}

This was a cross-sectional multicenter study with IBD patients that responded to IFX therapy after 14 weeks, in maintenance therapy. Blood samples were collected before infusions in order to check IFX levels. Previously defined demographic characteristics were retrospectively collected from the patients' charts and a specific protocol was then fulfilled.

\section{Inclusion and exclusion criteria}

Patients with a diagnosis of IBD (either CD or UC) confirmed by clinical, endoscopic, imaging and histological tests, that were treated with IFX for at least 14 weeks, were in clinical and/or endoscopic remission and signed the informed consent agreeing to participate could be included in the study. Patients who had their dose optimized according to physicians' perspective but were in stable doses for the last 6 months could also be included. Patients with undetermined IBD, primary non-responders to IFX and those with less than 18 years of age were excluded from the analysis.

Response and remission were defined by physician global assessment (PGA). Clinical response was defined as partial clinical improvement of symptoms (improvement of symptoms, with residual symptoms). Clinical remission was defined as complete absence of symptoms at the occasion of blood sample collection. Endoscopic remission was defined as absence of ulcers at colonoscopy (absence of active disease). The concomitant use of immunomodulators such as azathioprine (AZA) or methotrexate (MTX) at stable doses, and the use of corticosteroids in a dose of less or equal than $10 \mathrm{mg} /$ day of prednisone or equivalent, at the moment of blood sample collection, was also permitted.

\section{Blood sample collection}

Samples were collected before infusions (trough levels), and 10 $\mathrm{mL}$ of blood were put in standardized serum tube for each analysis, according to the kit manufacturer. The sample was centrifuged after harvesting ( $10 \mathrm{~min})$ and the serum should be transferred to a new tube (minimum of $200 \mu \mathrm{L}$ ). It was also recommended that the sample was stored for 24 hours at $-20^{\circ} \mathrm{C}$, and then sent on icepacks or dry ice to the laboratory so that it was always frozen until the moment of dosing.

\section{Blood sample analyses}

The standardization of the analyses was performed as follows. At the day of the infusion, ordinary routine blood tests (such as C-reactive protein and complete blood count, among others) and plasma for IFX-trough ELISA was collected in addition to $3 \mathrm{~mL}$ serum for QB-IFX rapid test. The serum was initially thawed, vortexed and $10 \mu \mathrm{L}$ were diluted in $190 \mu \mathrm{L}$ assay buffer and again vortexed for 5 seconds. An amount of $70 \mu \mathrm{L}$ was applied to the rapid test cassette and a 15 minutes timer was started. A new cassette was loaded every two minutes. After 15 minutes, the first cassette was read by using the QB-IFX dedicated electronic reader, by a previously trained nurse. Subsequently, a cassette was read every two minutes and thereafter.

After that, the same procedure was followed, but this time by a highly experienced laboratory technician that performed the ELISA. The ELISA used in our study was performed with a validated test (Ridascreen, R-Biopharm, Darmstadt, Germany) a 4-plate ELISA reader based on KU Leuven homecare ELISA ${ }^{(8,10)}$.

\section{Definitions}

The results of the analyses of the serum levels were described as undetectable, infra therapeutic or low (when detectable and below $3 \mu \mathrm{g} / \mathrm{mL}$ ), adequate (between 3.1 and $7.0 \mu \mathrm{g} / \mathrm{mL}$ ) and supra therapeutic or high (above $7.1 \mu \mathrm{g} / \mathrm{mL}$ ).

\section{Statistical analysis}

Statistical analyses were used according to SSPS v.16.0 software (IBM Inc., Armonk, NY, USA). The results were expressed as means \pm standard deviation (mean $\pm \mathrm{SD}$ ) for continuous variables and as frequency for categorical variables. For categorical variables Chi square or Fischer's exact test were used according to the expected values. Receiver operating characteristic (ROC) curves were drawn to determine the sensitivity ans specificity of the tests, in addition to comparing the QB-IFX rapid test with IFX-trough ELISA. Statistical significance was assumed if $P<0.05$ to all statistical tests.

\section{Ethical considerations}

This study was approved by the ethical boards of all institutions involved, under the CAAE number 22094913.7.0000.5411, at Plataforma Brasil website from the Brazilian Ministry of Health. 


\section{RESULTS}

A total of 51 patients met the inclusion criteria and initially were considered for the study. From those, two patients were excluded due to lack of data in some information at chart review. Thus, a total of 49 patients composed the final sample of the study and had the 2 tests for the comparison after blood collection.

The baseline characteristics of the patients are described in detail in TABLE 1. As seen, from the total sample of 49 patients, 34 had CD and 15 had UC as main diagnosis. In the CD group, mean disease duration was approximately 8 years and the mean age

TABLE 1. Baseline characteristics of the included patients.

\begin{tabular}{|c|c|}
\hline Baseline clinical characteristics & $\mathrm{CD}(\mathrm{n}=34)$ \\
\hline Male/female (\%) & $18 / 16(52.9 / 47.1)$ \\
\hline Median duration of disease (months) & $94.09 \pm 79.58$ \\
\hline Age (years) & $37.71 \pm 12.76$ \\
\hline Clinical remission (\%) & $34 / 34(100.0)$ \\
\hline Endoscopic remission (\%) & $30 / 34(88.2)$ \\
\hline \multicolumn{2}{|l|}{ Age at diagnosis ${ }^{a}$} \\
\hline A1 <16y (\%) & $3(8.8)$ \\
\hline A2 $17 y-40 y(\%)$ & $29(85.3)$ \\
\hline A3 > 40y $(\%)$ & $2(5.9)$ \\
\hline \multicolumn{2}{|l|}{ Disease location ${ }^{\mathrm{a}}$} \\
\hline L1 ileal (\%) & $4(11.8)$ \\
\hline L2 colonic (\%) & $20(58.8)$ \\
\hline L3 ileocolonic (\%) & $10(29.4)$ \\
\hline \multicolumn{2}{|l|}{ Disease phenotype $^{\mathrm{a}}$} \\
\hline B1 non-stricturing, non-penetrating (\%) & $24(70.6)$ \\
\hline B2 stricturing (\%) & $6(17.6)$ \\
\hline B3 penetrating $(\%)$ & $4(11.8)$ \\
\hline Perianal disease $(\%)$ & $11 / 34(32.4)$ \\
\hline Active smoking (\%) & $3 / 34(8.8)$ \\
\hline \multicolumn{2}{|l|}{ Medication profile } \\
\hline Mesalamine (\%) & $21 / 34(61.8)$ \\
\hline Previous steroids (\%) & $1 / 34(2.9)$ \\
\hline Combo/monotherapy (\%) & $21 / 13(61.8 / 38.2)$ \\
\hline Treatment duration with IFX (months) & $50.41 \pm 28.44$ \\
\hline Optimization of Infliximab (\%) & $14 / 34(41.2)$ \\
\hline Baseline clinical characteristics & $\mathrm{UC}(\mathrm{n}=15)$ \\
\hline Male/female (\%) & $8 / 7(53.3 / 46.7)$ \\
\hline Median duration of disease (months) & $85.60 \pm 53.83$ \\
\hline Age (years) & $44.07 \pm 19.26$ \\
\hline Clinic remission (\%) & $15 / 15(100.0)$ \\
\hline Endoscopic remission (\%) & $15 / 15(100.0)$ \\
\hline \multicolumn{2}{|l|}{ Disease phenotype ${ }^{a}$} \\
\hline E2 left sided colitis & $2 / 15(13.3)$ \\
\hline E3 pancolitis & $13 / 15(86.7)$ \\
\hline Active smoking (\%) & $1 / 15(6.7)$ \\
\hline \multicolumn{2}{|l|}{ Medication profile } \\
\hline Mesalamine (\%) & $10 / 15(66.7)$ \\
\hline Previous steroids (\%) & $0 / 15$ \\
\hline Combo/monotherapy (\%) & $10 / 5(66.7 / 33.3)$ \\
\hline Treatment duration with IFX (months) & $48.73 \pm 29.19$ \\
\hline Optimization of Infliximab (\%) & $8 / 15(53.3)$ \\
\hline
\end{tabular}

${ }^{a}$ According to Montreal classification; CD: Crohn's disease; UC: ulcerative colitis. was $37.71( \pm 12.76)$ years. The majority of patients had ileocolonic luminal CD. All patients were in clinical remission and the majority $(88 \%)$, in endoscopic remission, defined as absence of ulcers and inactive disease. In the UC group, patients had disease duration of approximately 7 years, with mean age of $44.07( \pm 19.26)$ years. Almost $90 \%$ of the patients had pancolitis and all of them were in clinical and endoscopic remission.

The main results of the study, according to the serum levels of IFX, are summarized in FIGURE 1. As seen, by using both methods, the majority of patients had low or adequate serum levels of IFX. Approximately one fourth of patients had undetectable serum IFX levels with both assays. In relation to the serum levels proportions by the two methods, there was no significant difference $(P=0.84)$.

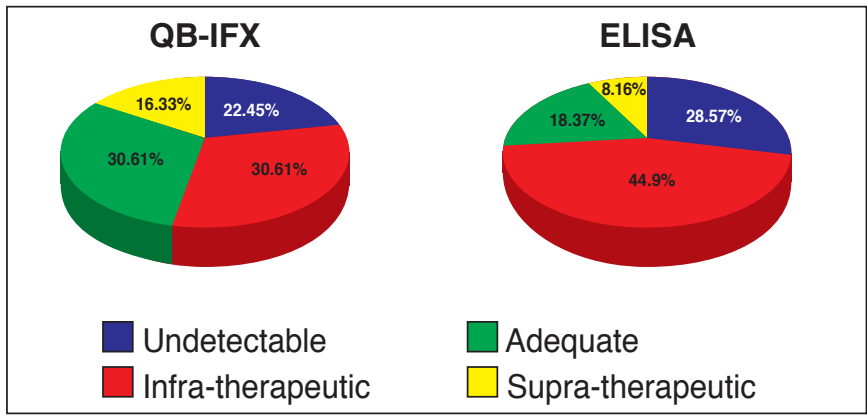

FIGURE 1. Serum levels of IFX with the two different techniques. Undetectable; Infra therapeutic $(0-3.0 \mu \mathrm{g} / \mathrm{mL})$; adequate $(3.1-7.0 \mu \mathrm{g} / \mathrm{mL})$; supra therapeutic (above $7.1 \mathrm{ug} / \mathrm{mL}$ ). Fisher's Exact Test, $P=0.84$.

The ROC analysis identified a concentration threshold $>2.9 \mu \mathrm{g} /$ $\mathrm{mL}$ with the QB-IFX test (FIGURE 2, area under the ROC, 0.82; $P<0.0001$, sensitivity, $100 \%$; specificity, $61.9 \%$ ), and $>3.83 \mu \mathrm{g} / \mathrm{mL}$ using the ELISA (FIGURE 3, area under the ROC, $0.96 ; P<0.0001$, sensitivity, $100 \%$; specificity, $92.9 \%$ ) for both methods, respectively. These cut-off values implied that $50 \%$ of patients had serum IFX concentrations lower than $2.9 \mu \mathrm{g} / \mathrm{mL}$ with the QB-IFX test, and 3.83 $\mu \mathrm{g} / \mathrm{mL}$ with the ELISA. The QB-IFX rapid test had a positive predictive value (PPV) of $29.9 \%$ and a negative predictive value (NPV) of $100.0 \%$. The ELISA assay had a PPV of $70.15 \%$ and a NPV of $100 \%$.

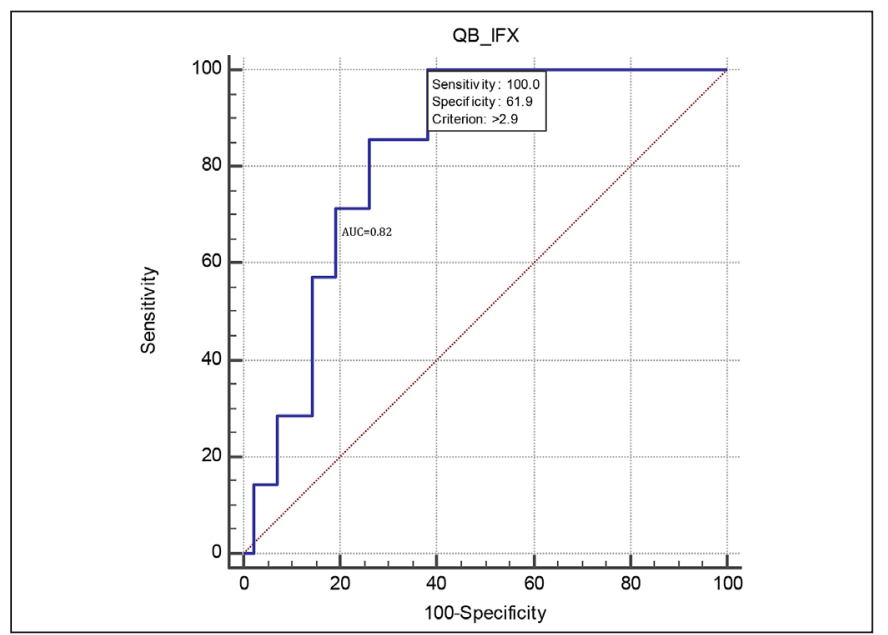

FIGURE 2. Rapid QB-IFX test IFX levels in patients with CD and UC. AUC: area under the curve. 


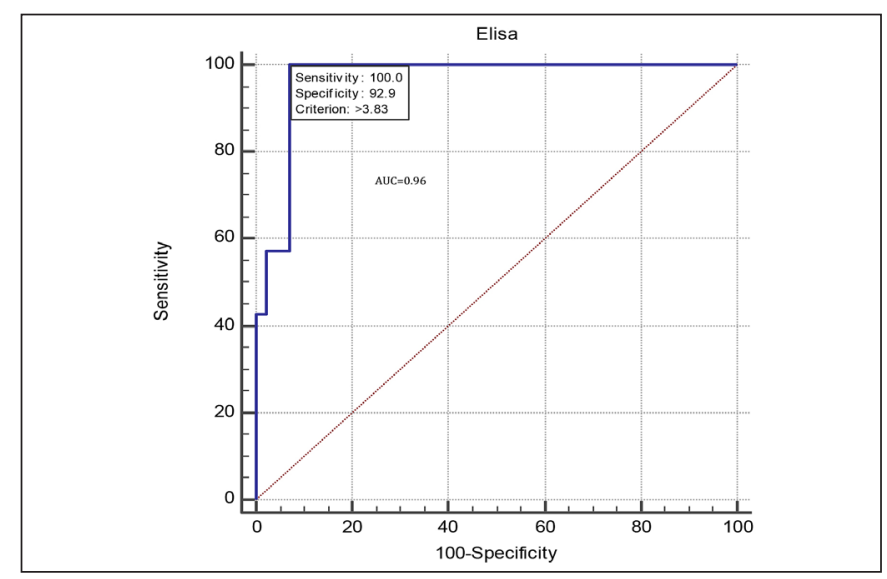

FIGURE 3. Elisa method of IFX levels in patients with CD and UC. AUC: area under the curve.

Moreover, when comparing the results by categories, we observed that undetectable and low serum levels of IFX $(0.0-2.9$ $\mu \mathrm{g} / \mathrm{mL}$ ) with QB-IFX had 100\% sensitivity and $61.9 \%$ specificity and with ELISA they had 100\% sensitivity and $92.8 \%$ specificity. For adequate levels (3.1-7.0 $\mu \mathrm{g} / \mathrm{mL})$, however, we observed regular sensitivity and high specificity of the two tests (QB-IFX: $54.1 \%$ sensitivity and $80.9 \%$ specificity; ELISA: $54.1 \%$ sensitivity and $97.6 \%$ specificity). Finally, we found a quite low specificity (QB-IFX: $28.5 \%$ sensitivity and $85.7 \%$ specificity; ELISA: $42.8 \%$ sensitivity and $100 \%$ specificity) for the two tests when the trough levels were supra therapeutic (above $7.0 \mu \mathrm{g} / \mathrm{mL}$ ).

Comparing the rapid QB-IFX test with the ELISA, on ROC analysis (FIGURE 4), the mean difference between areas $(0.82 ; 95 \%$ CI [confidence interval], 0.692-0.920, and 0.96; 95\% CI, 0.870-0.997, respectively) was $0.139 \pm 0.06 ; 95 \% \mathrm{CI}, 0.00778-0.271(P=0.03)$.

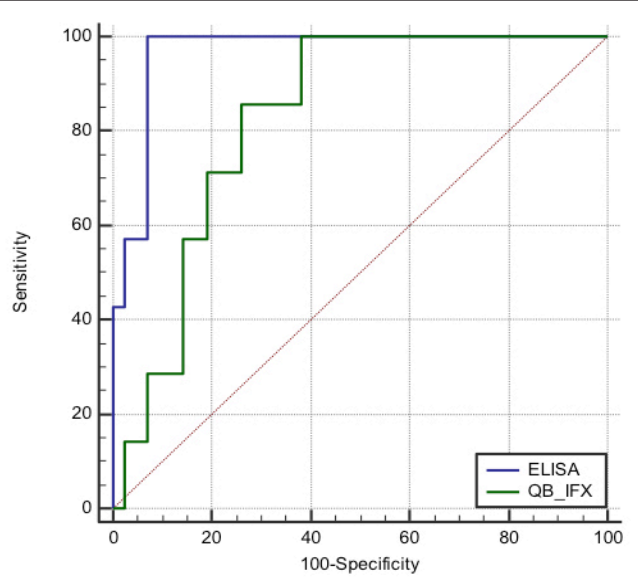

FIGURE 4. Comparison between the Elisa assay of IFX levels with QB-IFX rapid test in patients with $\mathrm{CD}$ and UC. AUC: area under the curve. Elisa methods: AUC: $0.966 \pm 0.02$ (95\% CI: 0.87-0.99). QB-IFX: AUC: $0.827 \pm 0.06$ (95\% CI: 0.69-0.92). Difference between areas $=0.139(P=0.03)$.

\section{DISCUSSION}

TDM has being described as an important strategy to identify and optimize loss of response to IFX and even to predict long-term response to IFX after induction ${ }^{(8,10,15,16)}$. There is clear evidence show- ing that therapeutic optimization may improve clinical remission ${ }^{(8,17)}$. Besides, several prospective studies have also demonstrated that concentration-based dosing (TDM) is also a cost-effective alternative to clinically based dosing optmization ${ }^{(8,17)}$. Several TDM algorithms have been created in order to assist the physician to the therapeutic decision-making process. For instance, in cases of supra-therapeutic IFX level, a de-escalation may save payer's' budget and also may decrease the rates of adverse events related to $\operatorname{IFX}^{(8,17)}$.

The conventional assays used for TDM are mostly based in ELISA methods ${ }^{(11,14,18)}$. The ELISA assays are usually performed in laboratory facilities and they are usually time-consuming. Moreover, to be cost effective, ELISA require analysis of multiple samples at the same time ${ }^{(20)}$. Thus, due to these well described limitations, the results of ELISA take at least one or two days to be available to be used in clinical practice. As the blood samples necessary for the trough level tests are collected immediately before the infusion, it means that these results are not going to be useful until the next infusion. As a consequence, ELISA IFX levels tests do not allow immediate dose escalation or de-escalation and may generate difficulties in implementing TDM in a hospital or in an infusion unit $^{(8,11-13,17)}$. Despite all these considerations with the ELISA, they still constitute the standard method in which TDM is based.

In order to bring TDM more applicable in real world clinical practice, a fast trough level measurement test is required. Recently, some rapid tests to measure IFX trough levels were described ${ }^{(14,18-20)}$. Moreover, rapid tests must be validated in accordance with standard ELISA assays that have being used so far. Lindsjø et al., from Norway, compared Quantum Blue Infliximab test (QB-IFX) to an unspecified ELISA ${ }^{(14)}$. The authors showed a good correlation between the two tests: QB-IFX rapid test versus ELISA, $r=0.91$, with $P<0.001$. In addition, the authors also reported that the rapid test was easy to perform and could be done by a non-trained laboratory employee. The correlation of the results of QB-IFX performed by a nurse or performed by a laboratory technician was also adequate, $\mathrm{r}=0.92, P<0.001^{(14)}$.

Recently, Van Stappen et al., from the University of Leuven, Belgium, have evaluated a novel rapid test LFA (lateral flow-based assay) and validated with an ELISA assay. The LFA (R-Biopharm AG, Darmstadt, Germany) was compared to a specific ELISA assay (Ridascreen, R-Biopharm, Darmstadt, Germany), both using a specific monoclonal anti-IFX antibody mAb-IFX6B $7^{(18,20)}$. The LFA rapid test had an excellent correlation with this specific ELISA for quantification of IFX in anti-TNF naïve UC patients starting induction therapy ${ }^{(18)}$. The authors reported an IFX concentration threshold $\geq 2.1 \mu \mathrm{g} / \mathrm{mL}$ at week 14 using LFA (area under the curve of $0.819, P=0.008$, sensitivity $100 \%$, specificity $50 \%$ ) and $\geq 2.7 \mu \mathrm{g} / \mathrm{mL}$ using ELISA (area under the curve of $0.819, P=0.012$, sensitivity $100 \%$, specificity $50 \%$ ) to be associated to mucosal healing ${ }^{(18)}$.

Our study had a similar objective as the aforementioned studies, to compare a rapid test versus a conventional ELISA for IFX dosing. Interestingly, we did not find a good sensitivity between the two methods in supra-therapeutic levels. Adequate sensitivity was only found in undetectable, low or adequate serum levels of IFX. This means that QB-IFX test might not be an adequate alternative to be used in patients with serum levels above $7.1 \mu \mathrm{g} / \mathrm{mL}$ as the main test to guide dose de-escalation of IFX.

Trough level assays started to be marketed in Brazil in early 2017. So far, few studies were published reporting the use of TDM in Latin America, and they did not compare different assays as our study. They were just case series with a single method being used ${ }^{(12,13)}$. 
Our comparative analysis, as far as we know, represents the first cohort of Brazilian IBD patients in which the trough level measurement comparison was totally performed and analyzed in our country. Moreover, it is the first study in Latin America that compared two different methods for the detection of the IFX, representing a landmark in our continent. Over time, we hope that the implications of our results can be discussed in clinical practice. For instance, when an undetectable or low level of IFX is found in the QB-IFX rapid test, there is probably no need for the ELISA levels. However, due to the limited correlation in supra-therapeutic levels, in these situations with the rapid test, an ELISA is strongly suggested to guide therapeutic decisions of de-escalation, as decrease in the dose or increase in the intervals of IFX infusions.

Our study had significant limitations that need to be clarified during the analysis of the results. First, the sample of patients was reduced. Secondly, all the patients were in remission, a situation in clinical practice that usually does not require TDM. Measuring serum levels when there is loss of response to IFX is the main indication of this strategy. Therefore, more studies with active disease and clear definitions of loss of response could also be useful in current practice, and are awaited. Lastly, we compared the rapid test with a single ELISA, and several others are used over the world. Despite these limitations, the strength of our study, as previously stated, is that it constitutes the first Latin American study to compare two different assays in TDM with IFX in IBD.

In summary, QB-IFX and ELISA to measure IFX levels were comparable in this multicentric cohort of Brazilian IBD patients. Both methods were accurate and had adequate sensitivity and specificity to detect undetectable, low and adequate levels. In contrary, QB-IFX and ELISA had shown low specificity for supra therapeutic levels of IFX. The implementation of the rapid test in clinical practice is awaited, and prospective studies with the methods are warranted.

\section{Authors' contribution}

The manuscript was written by Teixeira FV, Sassaki LY, Magro DO and Kotze PG. All authors were involved with patient care, read and gave approval for the final version of the manuscript. All authors had full access to the data in the study and Kotze PG take responsibility for the integrity of the data and the accuracy of the data analysis. Baima JP, Saad-Hossne R and Coy CSR gave important intellectual contribution to the manuscript and were involved in patient care.

Teixeira FV, Sassaki LY, Saad-Hossne R, Baima JP, Magro DO, Coy CSR, Kotze PG. Dosagem do nível sérico do infliximabe em pacientes com doença inflamatória intestinal em remissão: uma análise comparativa de dois diferentes métodos em uma coorte multicêntrica brasileira. Arq Gastroenterol. 2018;55(2):192-7.

RESUMO - Contexto - A monitorização dos níveis séricos do infliximabe (IFX) é uma importante ferramenta para guiar a tomada de decisão nos pacientes com doença inflamatória intestinal. No presente momento existem dois tipos de métodos para quantificar nível sérico de IFX disponíveis no mercado: o ELISA e o teste rápido. O método ELISA é o mais usado em todo o mundo, todavia os resultados demoram de 1 a 2 dias para estar disponíveis para uso clínico. Além disso, o ELISA é um método que requer um técnico especializado para realizá-lo. Ao contrário, os resultados do teste rápido estão disponíveis em 20 a 30 minutos e esse pode ser realizado por um funcionário não especializado. Objetivo - O objetivo deste estudo foi comparar o teste rápido (QB-IFX) com o teste ELISA para determinação quantitativa do nível sérico de IFX em uma coorte de pacientes com doença inflamatória intestinal. Métodos - Foi realizado um estudo transversal multicêntrico com inclusão de 49 pacientes em terapia de manutenção com IFX. Amostra sanguínea para dosagem sérica do IFX foi coletada imediatamente antes da infusão. A dosagem sérica do IFX foi classificada em indetectável, baixo $(<3,0 \mu \mathrm{g} / \mathrm{mL})$, adequado $(3,1-7,0 \mu \mathrm{g} / \mathrm{mL})$ ou alto $(>7,1 \mu \mathrm{g} / \mathrm{mL})$. A sensibilidade e a especificidade de cada teste e a comparação entre os testes foram avaliados através de curva ROC. Resultados - Foram avaliados 34 pacientes com doença de Crohn e 15 pacientes com retocolite ulcerativa em remissão clínica da doença. A maioria dos pacientes apresentou níveis baixos ou adequados do IFX sérico de acordo com ambos os métodos de dosagem. Não houve diferença significativa entre os métodos quando avaliados categoricamente $(P=0,84)$. A análise da curva ROC identificou limites de concentrações $>2,9 \mu \mathrm{g} / \mathrm{mL}$ com o teste rápido QB-IFX (AUC ROC, 0,82; $P<0,0001$, sensibilidade: 100\%; especificidade: $61.9 \%$ ), e $>3,83 \mu \mathrm{g} / \mathrm{mL}$ usando o método ELISA (AUC ROC, 0,96; $P<0,0001$, sensibilidade: 100\%; especificidade: $92,9 \%$ ). Conclusão - Os testes QB-IFX e ELISA foram comparáveis para dosagem do nível sérico de IFX. Ambos os métodos são acurados e apresentaram boa sensibilidade e especificidade para detecção de níveis indetectáveis, níveis baixos e níveis adequados, porém mostraram pouca especificidade para níveis supra terapêuticos da droga.

DESCRITORES - Doença de Crohn. Proctocolite. Infliximab. Monitoramento de medicamentos.

\section{REFERENCES}

1. Garcês S, Demengeot J, Benito-Garcia E. The immunogenicity of anti-TNF therapy in immune-mediated inflammatory diseases: a systematic review of the literature with a meta-analysis. Ann Rheum Dis. 2013;72:1947-55.

2. Maxwell LJ, Zochling J, Boonen A, Singh JA, Veras MM, Tanjong Ghogomu E, et al. TNF-alpha inhibitors for ankylosing spondylitis. Cochrane Database Syst Rev. 2015;4:CD005468.

3. Lemos LL, de Oliveira Costa J, Almeida AM, Junior HO, Barbosa MM, Kakehasi AM, et al. Treatment of psoriatic arthritis with anti-TNF agents: a systematic review and meta-analysis of efficacy, effectiveness and safety. Rheumatol Int. 2014;34:1345-60.

4. Fiorino G, Allez M, Malesci A, Danese S. Review article: anti TNF-alpha induced psoriasis in patients with inflammatory bowel disease. Aliment Pharmacol Ther 2009;29:921-7.
5. Lawson MM, Thomas AG, Akobeng AK. Tumor necrosis factor alpha blocking agents for induction of remission in ulcerative colitis. Cochrane Database Syst Rev. 2006;(3):CD005112.

6. Nam JL, Ramiro S, Gaujoux-Viala C, Takase K, Leon-Garcia M, Emery P, et al. Efficacy of biological disease-modifying anti rheumatic drugs: a systematic literature review informing the 2013 update of the EULAR recommendations for the management of rheumatoid arthritis. Ann Rheum Dis. 2014;73:516-28.

7. Kawalec P, Mikrut A, Wiśniewska N, Pilc A. Tumor necrosis factor- $\alpha$ antibodies (infliximab, adalimumab and certolizumab) in Crohn's disease: systematic review and meta-analysis. Arch Med Sci. 2013;9:765-79.

8. Van de Casteele N, Ferrante M, Van Assche G, Ballet V, Compernolle G, Van Steen K, et al. Trough concentrations of infliximab guide dosing for patients with inflammatory bowel disease. Gastroenterology. 2015;148:1320-9. 
9. Van de Casteele N, Khanna R, Levesque BG, Stitt L, Zou GY, Singh S, et al. The relationship between infliximab concentrations, antibodies to infliximab and disease activity in Crohn's disease. Gut. 2015;64:1539-45.

10. Van de Casteele N, Buurman DJ, Sturkenboom MGG, Kleibeuker JH, Vermeire $\mathrm{S}$, Rispens T, et al. Detection of infliximab levels and anti-infliximab antibodies: a comparison of three different assays. Alimentary Pharmacol Ther. 2012;36:765-71.

11. D'Haens GR, Vermeire S, Lambrecht G, Baert FJ, Bossuyt P, Pariente B, et al Increasing Infliximab Dose Based on Symptoms, Biomarkers, and Serum Drug Concentrations Does Not Increase Clinical, Endoscopic, or Corticosteroid-Free Remission in Patients With Active Luminal Crohn's Disease. Gastroenterology. 2018;154:1343-51.e1.

12. Kampa KC, Morsoletto DBG, Loures MR, Pissaia A Junior, Nones RB, Ivantes CAP. Importance of measuring levels of infliximab in patients treating inflammatory bowel disease in a Brazilian cohort. Arq Gastroenterol. 2017;54:333-7.

13. Parra RS, Feitosa MR, da Rocha JJR, Feres O. Higher trough concentrations of infliximab are associated with clinical remission and mucosal healing in patients with inflammatory bowel disease. J Inflam Bowel Dis \& Disord. 2016,1:104. doi:10.4172/jibdd.1000104

14. Lindsjø I, Malmstrøm GH, Røseth AG. Patient-near Infliximab trough-level testing by a novel quantitative rapid test: The Quantum Blue Infliximab test. United European Gastroenterol J. 2016;4(5S):P422.

15. Bortlik M, Duricova D, Malickova K, Machkova N, Bouzkova E, Hrdlicka L, et al. Infliximab trough levels may predict sustained response to infliximab in patients with Crohn's disease. J Crohns Colitis. 2013;7:736-43.
16. Arias MT, Vande Casteele N, Vermeire S, de Buck van Overstraeten A, Billiet $\mathrm{T}$, Baert F, et al. A panel to predict long-term outcome of infliximab therapy for patients with ulcerative colitis. Clin Gastroenterol Hepatol. 2015;13:531-8.

17. Steenholdt C, Brynskov J, Thomsen OO, Munck LK, Fallingborg J, Christensen LA, et al. Individualized therapy is more cost-effective than dose intensification in patients with Crohn's disease who lose response to anti-TNF treatment: a randomized, controlled trial. Gut. 2014;63:919-27.

18. Van Stappen T, Bollen L, Vande Casteele N, Papamichael K, Van Assche G, Ferrante $\mathrm{M}$, et al. Rapid Test for Infliximab Drug Concentration Allows Immediate Dose Adaptation. Clin Transl Gastroenterol. 2016;7:e206.

19. Corstjens PL, Fidder HH, Wiesmeijer KC, De Dood CJ, Rispens T, Wolbink GJ, et al. A rapid assay for on-site monitoring of infliximab trough levels: a feasibility study. Anal Bioanal Chem. 2013;405:7367-75.

20. Lu J, Van Stappen T, Spasic D, Delport F, Vermeire S, Gils A, et al. Fiberoptic-SPR platform for fast and sensitive infliximab detection in serum of inflammatory bowel disease patients. Biosens Bioelectron. 2016;79:173-9.

21. Magro F, Afonso J, Lopes S, Coelho R, Gonçalves R, Caldeira P, et al. Clinical performance of an infliximab rapid quantification assay. Therap Adv Gastroenterol. 2017;10:651-60.

22. Afonso J, Lopes S, Gonçalves R, Caldeira P, Lago P, Tavares de Sousa H, et al; Portuguese IBD Study Group (GEDII). Proactive therapeutic drug monitoring of infliximab: a comparative study of a new point-of-care quantitative test with two established ELISA assays. Aliment Pharmacol Ther. 2016;44:684-92. 